\title{
Investigating the Motivating Factors That Influenced the University of Namibia First Year Undergraduate Student Teachers to Choose Teaching as Career: A Case Study
}

\author{
Lukas Homateni Julius \\ Language Centre, University of Namibia \\ E-mail: ljulius@unam.na \\ Linus Kambeyo \\ Faculty of Education, University of Namibia, Namibia \\ E-mail:1kambeyo@unam.na
}

Received: May 12, 2020

Accepted: July 20, 2020

Published: August 1, 2020

doi:10.5296/jse.v10i3.17250

URL: https://doi.org/10.5296/jse.v10i3.17250

\begin{abstract}
This study investigates factors that motivated the first year undergraduate student teachers for choosing teaching as a career and also explores their perceptions about the teaching profession in Namibia. The study consists of 80 First year student teachers, 40 from Hifikepunye Pohamba campus, and 40 from Khomasdal campus. Quantitative approach was used to identify some of the factors that motivated students to choose teaching as a career. Factor Influencing Teaching choices scale (FIT scale: Watt \& Richardson, 2007) was used to investigate the student teachers' motivation and perception of teaching as a career. Analysis of the data reveals that most of the participants value making social contribution and shaping children's future. Moreover, factors such as university admission requirements, gender, stereotype of different grade level specialization, finance and the general socio-cultural image of teaching as a career in Namibia, among others, shaped the participants' motivations and perceptions.
\end{abstract}

Keywords: Motivation, teaching career, perceptions, social contribution 


\section{Introduction}

Teaching profession is inevitably the backbone of any aspiring knowledge based society. However, Namibia faces challenges in recruiting and retaining qualified teachers. Despite government efforts of mass training of teachers and tactics, such as the bush allowances, to retain them in the profession, there remain an overwhelming evidence that severe qualified teacher shortage persists especially in public schools (Ministry of Basic Education, 2016). According the Ministry of Education, the country needs about 6000 qualified teachers to solve the current teacher shortage. In 2014 there were about 1208 posts that are filled by unqualified teachers (teachers with other qualifications but do not have teacher training) and about 3000 under qualified teachers (teachers without any qualifications/in the process of attaining them) (Nhongo, 2014). Although the severe shortage is attributed to improper demand and supply model in place to predict the number of teachers needed within a timeframe, there is also an issue of teachers resigning a few years just after they have joined the profession.

Guajardo (2011) identifies eight useful interconnected categories that influence teacher motivation in developing countries: (1) workload and challenges (increasing demands on teachers and classroom challenges), (2) remuneration and incentives (teachers' salary deemed generally low), (3) Recognition and prestige (social respect for teachers have fallen in many countries), (4) accountability (teachers often face weak accountability with little support), (5) Career development (teaching is regarded as a second choice job with few opportunities for professional development), (6) institutional environment (teachers face unclear, constantly changing policy as well as poor management), (7) voice (teachers barely have opportunity for input into school management and ministry policies), (8) learning materials and facilities (teachers are expected to deliver with few or poor learning materials and poor facilities). All these categories identify with teachers who are already in the profession. One thing that remain under researched however, is what motivate people to choose teaching as a career in Namibian context.

Therefore, the purpose of this study is to investigate and explore factors that motivate student teachers' choices of teaching career. The study intends to bridge the gap between the existing literature about motivations for entering the teaching profession and motivations to teach, from a Namibian point of view. This study investigates factors that motivated the first year pre-service undergraduate student teachers for choosing teaching as a career and explores their perceptions about the teaching profession in Namibia. The study focuses on two research questions:

1. What are the factors that influence pre-service student teachers' motivations for choosing a teaching career?

2. What are the pre-service student teachers' perceptions about the teaching profession in Namibia? 


\section{Literature Review}

International bodies of research on motivation to become a teacher have categorized factors influencing the decision as comprising of intrinsic, extrinsic, and altruistic factors amongst others. In general, love or passion for teaching, contributing to society and helping others, and having positive experience at school are reported as important intrinsic and altruistic motivations for entering the teaching profession (Brookhart \& Freeman, 1992; Farka, Johnson, \& Foleno, 2000; Reif \& Warring, 2002; Richardson \& Watt, 2006). Additionally, research has also found that subject matter is a cardinal driving force in secondary teacher candidates' desire and motivation to teach (Andrew \& Hatch, 2002; Barnes, 2005; Jarvis \& Woodrow, 2005; Wang, 2004, Younger, Brindley, Pedder, \& Hagger, 2004). However, wanting to work with children may also be of paramount importance to the decision for student teachers in the elementary education or primary education or foundation phase (McCray, Sindelar, Kilgore, \& Neal, 2002; Reif \& Warring; 2002; Richardson \& Watt, 2006). Furthermore, the discourse on this issue has also alluded that one's perceived teaching ability may also play a major role in influencing students' decision to teach (King, 1993; Harms \& Knobloch; 2005, Milanowski, 2003; Richardson \& Watt, 2006).

A number of studies on a smaller number of student teacher candidates' career motivation suggested that social influences from family, friends, and community members were important determinants to the decision of becoming a teacher (King, 1993; McCray et al, 2002; Miller \& Endo, 2005; Su, 1996; Williams, Graham, McCary-Henderson, \& Floyd, 2009).

Research regarding extrinsic motivations for teaching produced very diverse results. Some studies found that factors such as having time with family and job stability are very important to the choice of a teaching career (Farkas et al., 2000, Milanowski, 2003; Reif \& Warring, 2002). Other research found that the salary and social status of teachers were not considered as important factors in participants' decision to becoming teachers (Richardson \& Watt, 2006). On the other hand, results from other studies suggested that financial concerns usually appeared to a stumbling block rather than as a factor that motivates people to teach (Beng Huat, 2004; King, 1993; Su, 1996; Williams et al., 2009). Results from the study by (Lortie,1975) suggested that teachers were reluctant to admit explicitly the role of material rewards in their decision to enter teaching, due to the emphasis on teaching as a service and a profession of dedication. He suggests "such normative pressures make it probable that material benefits influence teachers' decision more than their answers indicate" (p.30).

The relationship between pre-service teachers' motivation for teaching and their later career decisions is well established and hardly there are few studies, if not none in this regard in Namibia. Internationally, several studies have been carried out so far, for example a study by two Australian scholars, who examined how factors influencing pre-service teachers' choice of a teaching career were related to their planned persistence in teaching (Watt \& Richardson, 2008). The researchers found that a many of the student teachers who chose to teach based on factors such as, a passion for teaching, a desire to work with children, and a hope to make a difference in their lives indicated that they are content with their choice and intend to teach 
for their whole careers. Interestingly, results from this study (Watt \& Richardson, 2008), showed that individuals who chose teaching because it offered a satisfying career and supported their family life also planned to spend their whole career in teaching. However, whether such relationship exists among student teachers in different cultural and educational settings, especially in Namibia is yet to be discovered.

In contrast to the growing research activities on motivations for the choice of a teaching career, there is very limited literature about factors influencing the decision to teach in Namibia as a whole. Furthermore, the available studies in this area from the international scene provided varied findings. Farkas and colleagues (2000) found that working conditions, such as administrative support, parental support, and student behavior, were considered significantly more important to new teachers' choice of where to teach than was salary. The study further suggests that money can be effective in attracting teachers only if other critical working conditions are in place. This is in line with what (Farkas et al.,2000; Johnson \& Birkeland, 2003)'s findings which suggested that teachers' career decisions were influenced by a sense of success, which was significantly related to the working environment. Another study (Tamir, 2009) asserts that graduates of elite colleges who chose to teach in urban schools were inspired by a sense of mission to change society and make a difference in the lives of poor inner-city children. However, due to the small sample size (10 participants) and the special characteristics of the participants, it is hard to generalize from this study.

Two other related studies contributed critically to what influences people's choices to teach in certain geographical settings. Boyd and colleagues (Boyd et al., 2005) found that distance and hometown region had powerful effects on individuals' choices of where to teach. Beginning teachers had a strong preference to locate their first job close to their hometown, or in regions similar to that of their hometowns. Consistent with Boyd and colleagues' finding, Strunk and Robinson (2006) suggested that teachers preferred to teach in schools where the student and/teaching staff reflected their own identity in order to seek racial similarity and comfort.

\section{Theoretical Framework}

The current study draws its theoretical framework from the Expectancy-Value Theory. The theory proposes that individuals' expectancies for success and the values they have for succeeding are important determinants of their motivation to perform different tasks (Atkinson,1957, Eccles et al., 1983). Early research suggests that expectancies are individuals' anticipation that their performance will be followed by either success or failure, and value as the relative attractiveness of succeeding or failing on a task (Atkinson, 1957).

Eccles and colleagues (Eccles et al., 1983) expanded the theory and created an expectancy-value model of achievement choice to examine adolescents' performance and choice in the mathematics achievement. The model contained several belief and value constructs including: subjective task values, expectancies for success, achievement goals, and beliefs about ability or competence. Eccles and colleagues proposed four major components of subjective values: attainment value or importance, intrinsic value, utility value or usefulness of the task, and cost (Eccles et al., 1983; Wigfield \& Eccles, 1992). Attainment 


\section{Macrothink}

value refers to the importance of doing well on a given task. Intrinsic value is the enjoyment one gains from doing the task. Utility value refers to how a task fits a requirement for a science degree. Cost refers to what the individual has to give up to perform a task.

The Expectancy-Value Theory was further developed by Watt and Richardson (Richardson \& Watt, 2006; Watt \& Richardson, 2007), who applied the theory to understand beginning education students' choice of a teaching career. Based on three major variables in Eccles et al.'s model - ability beliefs, values, and task perceptions, they created the Factors Influence Teaching (FIT) Choice Scale. Figure 1 illustrates the new framework, which contains antecedent socialization, followed by task perception, self-perceptions, and values. In the FIT Choice scale, the subjective attainment value in Eccles et al.'s model was renamed as personal utility value, and utility value as social utility value. The cost construct was renamed as task perception. Each higher order construct in turn contains first-order constructs. Expert career and high demand comprised task demand, while social status and salary comprised task return. Job security, time for family, and job transferability comprise the personal utility value construct; whereas shape the future of children/adolescents, enhance social equity, make social contribution, and work with children comprise the social utility value (Richardson \& Watt, 2006).

Based on the literature, the present study hypothesizes that the Expectancy-Value model offers a comprehensive theoretical framework to understand pre-service teachers' initial motivations to become teachers. According to the expectancy-value theory, the subject value of a certain task results from the interaction of its composing constructs. Figure 1 illustrates the structure and components of motivations for choosing a teaching career 


\section{Socialization} Influences

Social dissuasion Prior T\&L experiences

Social influences

\begin{tabular}{|l|}
\hline Task demand \\
Expert career \\
High demand \\
Task return \\
Social status \\
Salary \\
\hline
\end{tabular}

\section{Self perceptions}

Perceived teaching abilities

\begin{tabular}{|l|}
\hline Intrinsic value \\
Personal utility value \\
Job security \\
Time for family \\
Job transferability \\
Social utility value \\
Shape future of children/adolescent \\
Enhance social equity \\
Make social contribution \\
Work with children/adolescents \\
\hline
\end{tabular}

Fallback career

Figure 1. The FIT-Choice framework (Richardson \& Watt, 2006, p. 32)

\section{Methodology}

The purpose of this study was to explore pre-service students' motivations for choosing a teaching career. The target population for the current study included a group of 80 pre-service student-teachers from 2 campuses of the University of Namibia, Hifikepunye Pohamba Campus and Khomsdal Campus.

Data was collected using FIT-Choice Scale (Table 1), an instrument developed by Richardson and Watt (2006) and validated on two large samples of pre-service teachers in two Australian universities (Watt \& Richardson, 2007). Based on the FIT-Choice framework, the scale contains the values, beliefs, and socialization influences constructs, which are comprised of four higher order constructs, first-order constructs, and questions. The level of satisfaction with the decision to teach is used as the indicator of pre-service teachers' future choice of a teaching career in the scale. Table 1 depicts the scale with sample questions. Participants were asked to rate each item on a 7 point Likert scale. 


\section{$\triangle$ Macrothink}

Table 1. FIT-Choice Scale (Adapted from Richardson and Watt, 2006, pp. 34-36).

\begin{tabular}{|c|c|c|c|}
\hline $\begin{array}{l}\text { Higher-order } \\
\text { Factor }\end{array}$ & Factor & Sample Questions & Anchors \\
\hline \multicolumn{4}{|c|}{ Influential factors: I chose to become a teacher because... } \\
\hline $\begin{array}{l}\text { NA } \\
\text { N/A } \\
\text { N/A } \\
\text { Personal utility } \\
\text { value }\end{array}$ & $\begin{array}{l}\text { Ability } \\
\text { Intrinsic career } \\
\text { value } \\
\text { Fallback Career } \\
\text { Job security } \\
\text { Time for family } \\
\text { Job transferability } \\
\text { Shape future of } \\
\text { children/ } \\
\text { adolescents enhance } \\
\text { social equity } \\
\text { Make social } \\
\text { contribution } \\
\text { work with children } \\
\text { Prior teaching and } \\
\text { learning experiences } \\
\text { Social influences }\end{array}$ & $\begin{array}{l}\text { Teaching is a career suited to my } \\
\text { abilities. } \\
\text { I have always wanted to become a } \\
\text { teacher. } \\
\text { I was unsure of what career I wanted } \\
\text { Teaching will offer reliable income. } \\
\text { Teaching hours will fit with the } \\
\text { responsibilities of having family. } \\
\text { A teaching job will allow me to } \\
\text { choose where I wish to live } \\
\text { Teaching will allow me to have an } \\
\text { impact on children/adolescents. } \\
\text { Teaching will allow me to work } \\
\text { against social disadvantage. } \\
\text { Teachers make a worthwhile social } \\
\text { contribution. I want a job that } \\
\text { involves working with } \\
\text { children/adolescents. } \\
\text { I have had teachers as role models. } \\
\text { My family think I should become a } \\
\text { teacher }\end{array}$ & $\begin{array}{l}1 \text { (not all } \\
\text { important), to } 7 \\
\text { (Extremely } \\
\text { Important) }\end{array}$ \\
\hline
\end{tabular}

\subsection{Samples}

The sample of this study consisted of 80 student teachers ( 40 from HP campus and 40 From Khomasdal Campus). Of these participants, 50 were female and 30 were males. At the time of this study, all the participants were registered first year pre-service/ student teachers studying towards the Bachelors of Education honours degree at the University of Namibia. Data was collected using the FIT-choice scale designed by Richardson and Watt (2006) and widely validated by various large samples including that of pre-service teachers in two Australian universities (Watt \& Richardson, 2007).

\subsection{Data collection and analysis}

Quantitative approach was used to identify some of the factors that motivated students to choose teaching as a career. Data collected were managed and analyzed using content analysis (Cohen, Manion \& Morrison, 2007), and themes emerged from the questionnaire items. Content analysis has been defined as a systematic, replicable technique for compressing many words of text into fewer content categories based on explicit rules of coding (Berelson, 1952; GAO, 1996; Krippendorff, 1980; and Weber, 1990). Holsti (1969) 
offers a broad definition of content analysis as, "any technique for making inferences by objectively and systematically identifying specified characteristics of messages" (p. 14). Under this definition, we were able to categorize and thematically analyzed the data. Content analysis also enabled us to sift through large volumes of data with relative ease in a systematic fashion (GAO, 1996). It has proven to be a useful technique as it allowed us to discover and describe the focus of individual, group themes, putting the factors together, or social attention. It also allows inferences to be made which can then be corroborated using other methods of data collection.

\section{Findings and discussions}

Preliminary finding reveals that majority of first year student teachers were females, which also influenced the number representing the gender participants in this study. Answering the question what motivated student teachers to choose teaching career, majority of participants reasoned that becoming a teacher enables them to shape children's future, make social contribution, ability to teach, and prior teaching experience. In other words, they (participants) started teaching as underqualified teachers, without teaching qualification, and wanted to become qualified teachers to secure their jobs. The participants also claim that teaching career offer more holidays which translate into more time with their families. Data further reveal that the university admission requirements also influenced the participant's choice of becoming teachers because they are more lenient compared to requirements such as those of becoming an engineer or career in Information technology (IT). Student teachers in the study perceived teaching as a career that is high in demand but low in return. They believed teaching, comes with heavy workload, is emotionally demanding, and requires hard work and expert knowledge. However, teaching does not offer good salary and teachers do not have a high social status compared to other professions, such as engineers and medical doctors in Namibia.

One of the research question asked what factors influenced pre-service teachers' choice of a teaching career. The findings revealed that 12 motivation factors influencing participants' choice of a teaching career (see Figure 2). As illustrated in figure 2, the highest rated motivations for becoming a teacher included shape the future, work with children, make social contribution, perceived teaching ability, and prior teaching and learning experiences. The lowest rated motivations were choosing teaching as a fallback career, followed by time for family. Ranked in between were intrinsic career value, the desire to enhance social equity, job security, social influence, and job transferability. 


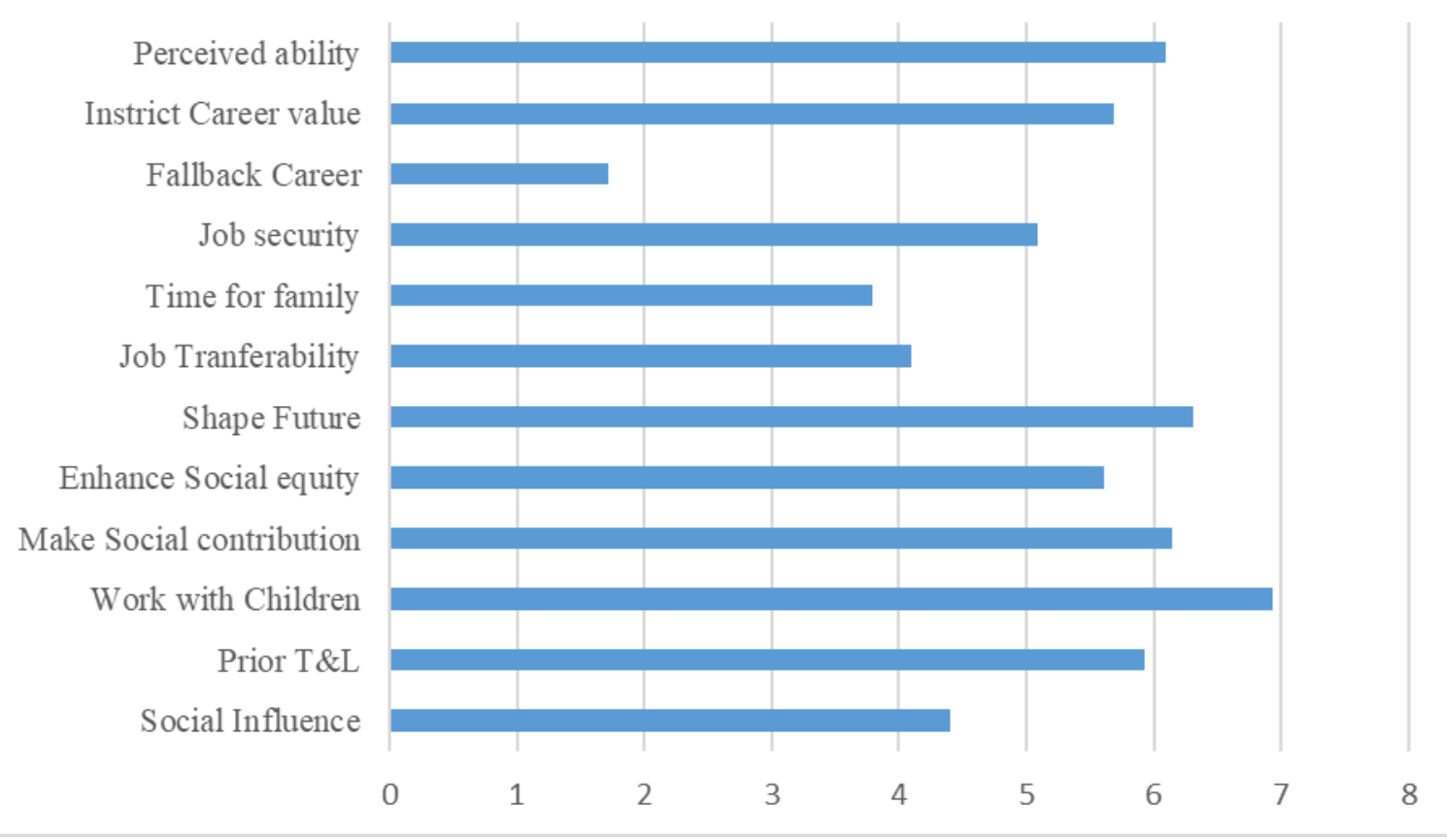

Figure 2. Motivation for choosing the teaching career

A couple of differences were evident between the findings of present study and that of Richardson and Watt (2006). First of all, our participants were few, only 80. Most of our participants rated four out of the highest rated factors more as compared to the rating in Richardson and Watt's study. While factors such as shape the future, work with children, make a social contribution, and perceived teaching ability continued to be rated most important to the decision of becoming a teacher by participants in the present study, intrinsic career value was rated a relatively lower than in Richardson and Watt's, giving away its top five ranking to prior teaching and learning experiences (See Figure 2). Finally, time for family was rated the second lowest in the current study instead of social influence as in Richardson and Watt's study.

Consistent with previous research (Richardson \& Watt, 2006), pre-service teachers in the study perceived teaching as a career that is high in demand but low in return. Hence, people opt to be teachers initially and leave the teaching profession later in Namibia. They believed teaching has a heavy workload, is emotionally demanding, and requires hard word and expert knowledge. However, teaching does not offer good salary and teachers do not have a high social status. In spite of the high cost of teaching, participants reported high level of satisfaction with their choice of teaching though, (Figure 3). 


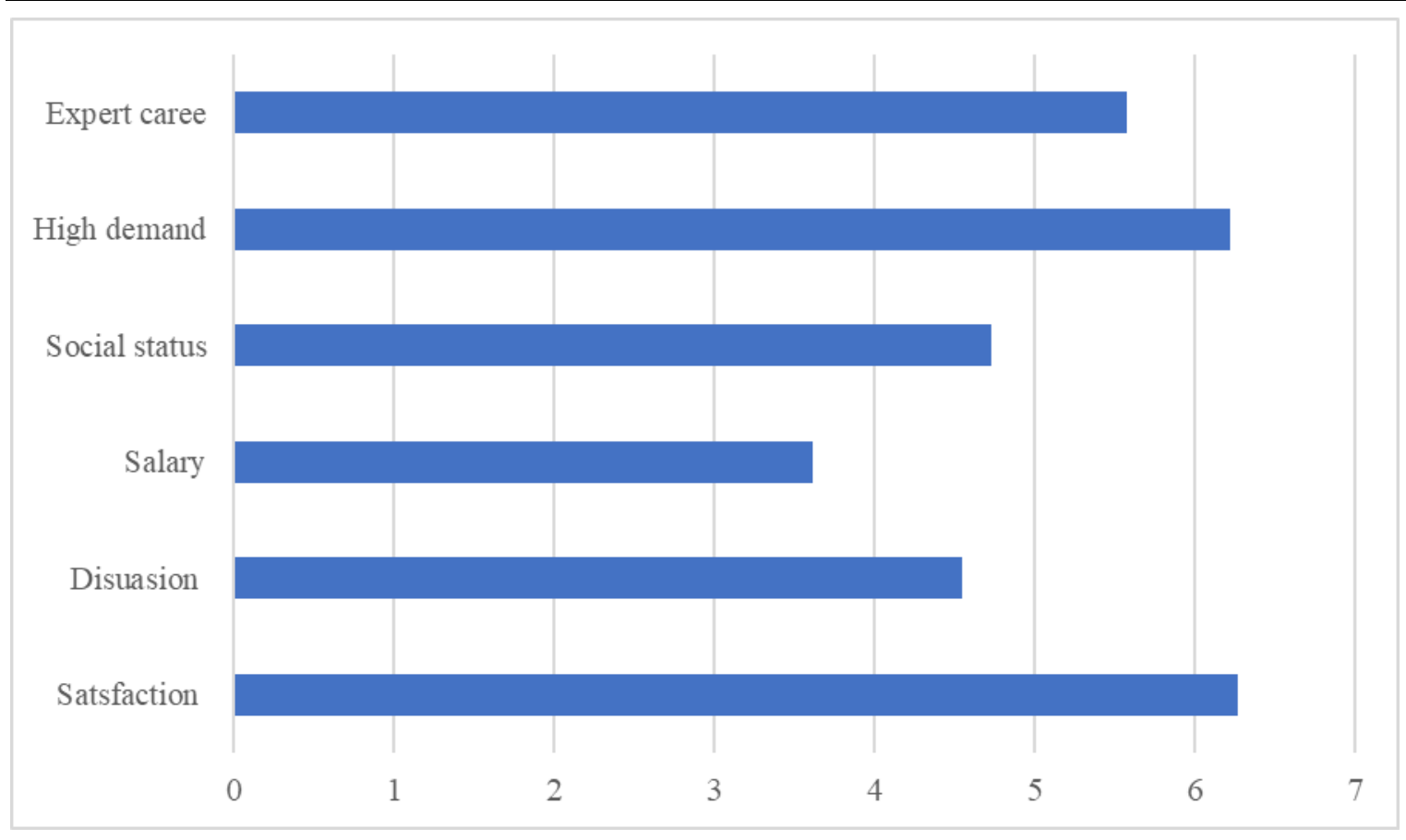

Figure 3. Perceptions of teaching and satisfaction with choice

\section{Conclusion}

This focused on identifying the motivate student teachers to choose a career in teaching, and partly to address the ongoing challenge of shortage of qualified teachers in many Namibian schools. Factors such as university admission requirements, gender, stereotype of different grade level specialization, finance and the general socio-cultural image of teaching as a career in Namibia, among others, shaped the participants' motivations and perceptions.

The Expectancy-Value model identified beliefs, values, and task perceptions that are hypothesized to be important to pre-service teachers' motivations for choosing a teaching career. Consistent with the previous research, the findings of the current study suggest that, in general, perceived teaching ability, passion for teaching, social value of the profession, and prior experience of teaching and learning are important determinants to the decision of becoming a teacher (Brookhart \& Freeman, 1992; Farka et al., 2000; Reif \& Warring, 2002; Richardson \& Watt, 2006). Personal values, social influence, and salary are considered less important to the decision (Richardson \& Watt, 2006).

The findings also offered valuable information about how motivations for teaching interact with each other. While the low rating may reflect that the factors have truly less important influence to the decision to become a teacher, the inter-factor relationships depict a fairly intricate network. Motivations contributing positively to the choice of a teaching career are not necessarily negatively related to the motivations that have negative influence on the choice. For instance, individuals who decide to become teachers because they want to make a difference and make a social contribution may also consider teaching as a stable job that offers the advantage for them to choose where to work and live. Similarly, the passion and love for teaching may be significantly influenced by the desire to spend more time with 
family. Likewise, teacher candidates who believe they have teaching ability and want to make a difference can be very realistic about the fact that teaching is a highly demanding profession which is also low in return. The "cost" can have positive influence on the satisfaction with the choice of teaching. The ultimate decision is not likely the result of either positive or negative motivations, rather the balance among the interactions of all factors.

The current study had some limitations. The one limitation of greatest concern to the authors is that the number of pre-service teachers who participated was not representative enough, as the participants only came from two campuses of the University of Namibia. Also 80 research samples were not enough a number to allow the use of Statistical Package for the Social Sciences (SPSS, 2012), for thorough analysis of data. Another limitation of the study is that data collection relied solely on a self-report survey. Since teaching is considered as a service and a profession of dedication (Lortie, 1975), participants might have felt reluctant to admit that they chose teaching due to personal values, or to material benefits of the profession. The influence of similar factors might not be accurately measured, and might be more important to the decision to become a teacher than the results indicated. Future studies need to consider using multiple data sources, gathered through both quantitative and qualitative methods, for in-depth information about the issue.

\section{References}

Andrews, P, \& Hatch, G. (2002). Initial motivations of serving teachers of secondary mathematics. Evaluation and Research in Education, 16(4), 185-201.

Atkinson, J. W. (1957). Motivational determinants of risk-taking behavior. Psychological Review, 64(6, Pt.1), 359-372. https://doi.org/10.1037/h0043445

Beng H. S. (2004). Determinants of teaching as a career in the UK. Evaluation \& Research in Education, 18(4), 213-242. https://doi.org/10.1080/09500790408668320

Boyd, D., Lankford, H., Loeb, S., \& Wyckoff, J. (2005). The draw of home: How teachers 'preferences for proximity disadvantage urban schools. Journal of Policy Analysis and Management, 24(1), 113-132. https://doi.org/10.1002/pam.20072

Brookhart, S.M., \& Freeman, D. J. (1992). Characteristics of entering teacher candidates. Review of Educational Research, 62 (1), 37-60. https://psycnet.apa.org/doi/10.2307/1170715

Cohen, L., Manion, L., \& Morrison, K. (2007). Research methods in education (6 ${ }^{\text {th }}$ ed.). London: Routledge.

Eccles (Parsons), J., Adler, T.F., Futterman, R., Goff, S. B., Kaczala, C. M., Meece, J.L., \& Midgley, C. (1983). Expectancies, values, and academic behaviors. In J. T. Spence (Ed.), Achievement and achievement motivation (pp. 75-146). San Francisco, CA: Freeman

Farkas, S., Johnson, J., Foleno, T. (2000). A sense of calling: Who teachers and why. A report from Public Agenda. Washington, DC: Thomas, B. Fordham Foundation; New York, NY: Open Society Inst. Retrieved from https://pdfs.semanticscholar.org/f3ba/8e5ded347b51e81a1562292b652fd94d5b35.pdf 


\section{Mll Macrothink}

Journal of Studies in Education

ISSN 2162-6952

2020, Vol. 10, No. 3

Guajardo, J. (2011). Teacher Motivation: Theoretical framework, situation analysis of Save the Children Country offices and recommended strategies. Accessed June10, 2018 from https://www.academia.edu/28952777/Teacher_Motivation_Theoretical_Framework_Situatio n_Analysis_of_Save_the_Children_Country_Offices_and_Recommended_Strategies

Harms, B., \& Knobloch, N. (2005). Pre-service teachers' motivation and leadership behaviors related to career choice. Career and Technical Education Research, 30(2), 101-124.

Ingersoll, R. M., \& May, H. (2011). The minority teacher shortage: Fact or fable? Phi Delta Kappan, 93(1), 62-65. https://doi.org/10.1177\%2F003172171109300111

Jarvis, J., \& Woodrow, D. (2005). Reasons for choosing a teacher training course. Research in Education, 73, 29-35. https://doi.org/10.7227\%2FRIE.73.3

Johnson, S. M., \& Birkeland, S. E. (2003). Pursuing a -sense of success": New teachers explain their career decisions. American Educational Research Journal, 40(3), 581-617. https://doi.org/10.3102\%2F00028312040003581

King, S. (1993). Why did we choose teaching careers and what will enable us to stay? Insights from one cohort of the African American teaching pool. Journal of Negro Education, 62(4), 475-492. https://doi.10.2307/2295518

Lortie, D. C. (1975). Schoolteacher: A sociological study. Chicago, IL: The University of Chicago.

McCray, A. D., Sindelar, P. T., Kilgore, K. K., \& Neal, L. I. (2002). African-American women's decisions to become teachers: Sociocultural perspectives. International Journal of Qualitative Studies in Education, 269-290. https://doi.org/10.1080/09518390210122845

Milanowski, A. (2003). An exploration of the pay levels needed to attract students with mathematics, science and technology skills to a career in K-12 teaching, Education Policy Analysis Archives, 11(50). Retrieved from http://epaa.asu.edu/epaa/v11n50/

Miller, P., \& Endo, H. (2005). Journey to becoming a teacher: The experiences of students of color. Multicultural Education, 13(1), 2-9.

Namibia, Ministry of Education (2014). Recruiting Qualified teachers from SADC Countries. Retrieved, June 25, 2016, from http://www.moe.go.na

Nhongo, K. (August 08, 2014). Teacher shortage alarming. Windhoek Observer. Retrieved January 26, 2016, from www.observer.com.na

Reif, M. T., \& Warring, D.F. (2002). Why teach: A comparative analysis of responses from prospective teachers enrolled in professional education program in 1991-92 with those in 2000-01. University of Saint Thomas. Retrieved from ERIC database. (ED 464068)

Richardson, P. W., \& Watt, H. M. G. (2006). Who chooses teaching and why? Profiling characteristics and motivations across three Australian universities. Asia-Pacific Journal of Teacher Education, 34(1), 27-56. https://doi.org/10.1080/13598660500480290 


\section{Ml Macrothink}

Journal of Studies in Education

ISSN 2162-6952

2020, Vol. 10, No. 3

Strunk, K. L., \& Robinson, J. P. (2006) Oh, won't you stay: A multilevel analysis of the difficulties in retaining qualified teachers. Peabody Journal of Education, 81(4), 65-94. https://doi.org/10.1177\%2F0022487113510743

$\mathrm{Su}, \mathrm{Z}$. (1996). Why teach: Profiles and entry perspectives of minority students as becoming teachers. Journal of Research \& Development in Education, 29(3), 117-133.

Tamir, E. (2009). Choosing to teach in urban schools among graduates of elite colleges. Urban Education, 44(5), 522-544. https://doi.org/10.1177\%2F0042085909339373

Wang, H. (2004). Why teach science? Graduate science students' perceived motivations for choosing teaching as a career in Taiwan. International Journal of Science Education, 26(1), 113-128. https://doi.10.1080/0950069032000070243

Watt, H. \& Richardson, P. (2007). Motivational factors influencing teaching as a career choice: Developmental validation of FIT-choice scale. Journal of Experimental Education, 75 (3), 167-202.

Watt, H. M. G., \& Richardson, P.W. (2008). Motivations, perceptions, and aspirations concerning teaching as a career for different types of beginning teachers. Learning and Instruction, 18(5), 408-428. https://doi.org/10.1016/j.learninstruc.2008.06.002

Watt, H., \& Richardson, P. (2007). Motivational factors influencing teaching as a career choice: Development and validation of the FIT-Choice Scale. Journal of Experimental Education, 75(3), 167-202. https://doi.org/10.3200/JEXE.75.3.167-202

Wigfield, A., \& Eccles, J. (1992). The development of achievement task values: A theoretical $\begin{array}{llll}\text { analysis. Developmental 265-310. } & \text { Review, }\end{array}$ https://doi.org/10.1016/0273-2297(92)90011-P

Williams, E., Graham, A., McCary-Henderson, S., \& Floyd, L. (2009). "From where I stand": African American teacher candidates on their decision to teach. Educational Forum, 73(4), 348-364. https://doi.org/10.1080/00131720903178742

Younger, M., Brindley, S., Pedder, D., \& Hagger, H. (2004). Starting points: Student teachers' reasons for becoming teachers and their preconceptions of what this will mean. European Journal of Teacher Education, 27(3), 245-264. https://doi.org/10.1080/0261976042000290787 